\title{
Clothes as Expression of Action in Former Concentration Camps
}

\author{
Claudia Theune ${ }^{1}$
}

Published online: 24 July 2017

(C) The Author(s) 2017. This article is an open access publication

\begin{abstract}
The prisoners of the former concentrations camps were supposed to be deprived of their socialization by brutal dehumanization. Among other things, the use of blue-and-white striped prison clothes was meant to reinforce a homogeneous and uniform prisoner society. However, studies from a sociological perspective have shown that prisoners' societies were indeed diverse and structured, allowing individuals to develop strategies of survival within their - albeit limited - scope for action. In this article, prisoners' possibilities to act are discussed using the example of clothing - an omnipresent and visible medium. Various changes and alterations preserved in prisoner clothing from former concentration camps reveal open or secretive acts of individuals and thus provide insights into the different levels of action inside the camps.
\end{abstract}

Keywords Prisoner clothes $\cdot$ Shoes $\cdot$ Social structures $\cdot$ Mauthausen $\cdot$ Sachsenhausen

\section{Introduction}

Almost two generations and more than 70 years after the liberation of National Socialist concentration and internment camps across Europe, the perception of those camps' complex organization, and social structures within them, seems to have become more and more non-hierarchical and simplified. In particular, in a historical perspective the suffering of prisoners and living conditions in concentration camps are being increasingly generalized in overviews. An adequate distinction between extermination camps, concentration camps and their sub-camps, forced labor camps, or other internment facilities with regard to their varying functions and survival chances of the interned, is being made less and less by those who write about the camps (Suderland 2013:4), including from an archaeological point of view (e.g., Sturdy Colls 2015).

Claudia Theune

Claudia.theune@univie.ac.at

1 Department of Prehistory and Historical Archaeology, University of Vienna, Franz-Klein Gasse 1, 1190 Vienna, Austria 
This "leveling" of hierarchies has been further extended by a disregard for the heterogeneity of prisoner societies and the diversity existing within them (Suderland 2013:4) by proclaiming the total annihilation of any prisoner's social individuality through symbolic, objective and subjective violence enacted by the National Socialists (Suderland 2008:252).

Countering this current trend, it needs to be emphasized that we are actually very well informed about the multi-layered and complex structure of prisoner society through testimonies of survivors given shortly after liberation. These accounts clearly show the diversity within the camp communities despite being confined in a sealed and controlled space with a constant threat of death (Sofsky 1993:35-37).

Eugen Kogon, imprisoned in Buchenwald from September 1939 -April 1945 and Paul Martin Neurath, who spent two years (1938-39) in the camps in Dachau and Buchenwald, gave detailed descriptions of the camps. As sociologists, both draw a complex picture of a diverse camp society that was determined by solidarity but also competition. In particular, Kogon emphasizes the pronounced hierarchy that was built on prisoners' national backgrounds as well as a struggle for privileged positions among the so-called political and criminal prisoners. He also mentions different structures within the group of guards (SS and prisoner functionaries). Arguments similar to Kogon's are apparent in the work of Paul Martin Neurath. He stresses that despite different social rules operating inside the camp, "basic concepts" of human society persisted (Neurath 2004:381; see also Suderland 2013:7-9, 56-97). Through their pre-camp socialization fellow inmates shared certain social rules, values, and practices that allowed to a certain degree the maintenance of a social identity, which in return enabled, to a modest extent, a sense of community, human dignity, and will for survival.

Beside the detailed research on concentration camps, the Holocaust, systematic extermination, and the violence and terror of the National Socialist dictatorship which has been primarily conducted by historians, archaeologists have also been investigating the material remnants of the camps. By combining the study of objects with word-based sources from victims and perpetrators, testimonies of survivors, and pictorial sources produced by victims and perpetrators, the remnants from environments of National Socialist terror are put in their contextualized historical reference. Such objects are interpreted as material witnesses of suffering, terror, powerlessness, and power, but also survival strategies (Theune 2016:65). Beside these investigations, there is a general failure to combine objects from excavations in former concentration camps or from collections of memorials with sociological theories and approaches.

What I am attempting in this chapter is a reflection on the social structures and possibilities to act inside concentration camps (not other internment camps) by examining seemingly visible characteristics of prisoners, namely clothing. Clothing plays an essential role in our lives. Beside the protective function against cold and heat, clothing has an important function in expressing one's social positions. It is normally obvious whether we wear new and upmarket or threadbare clothing, whether we place value on our wardrobe. Clothing is a relevant and crucial category to express social procedures and social positioning in a multi-layered society.

Clothes, including footwear, belong to a type of material culture, which due to the difficult conditions of preservation is not often at the center of archaeological or 
material culture-based research, although clothing plays such an essential role in human history. Looking more into detail in reports of archaeological excavations and in museum exhibitions, there are quite a few examples of jackets, shirts, dresses, trousers, shoes, gloves, and other clothing components.

Generally the sub-ground preservation conditions mean that certainly shoes or boots, whether they are made from leather or rubber or other alternative materials have a better chance of surviving than textiles. But as some of the former concentration camps are situated in forested and moist earth surroundings, there is also a chance of finding textiles. Recently a pit packed full with $10 \mathrm{~m}^{3}$ of shoe fragments was excavated at Sachsenhausen; at the site of the Gunskirchen sub-camp a quantity of clothing still survives on the forest floor (see below).

In particular the blue-and-white striped suit of the internees and also textile fragments with prisoners' labeling are stored in the memorials. These objects are an integral part of the exhibitions. The high symbolic value of the so - called "zebra suit" is also clear when looking at the commemorations in the memorials when survivors wear this suit while attending such events.

The question arises as to whether the remains of prisoners' clothes made from fabrics, leather, or other materials or even self-made clothes and shoes provide insights into prisoners' restricted possibilities to act. The prisoners' clothing was a permanently visible and obvious signifier of the prisoner community inside the camp. Other selfmade or altered (decorated) objects, which have already been analyzed in other contexts, will be included in the discussion in order to explore prisoners' scope of action and material practices that were part of survival strategies.

First I will depict an overview of prisoner societies in a sociological perspective. I will then give an introduction on the meaning of clothing in general and in the concentration camps in particular, also regarding written sources. I will briefly elaborate on the shoe testing track and the shoe factory in Sachsenhausen to highlight the importance of clothing for the SS organizing and running the camps and for the Wehrmacht. I will present and discuss clothing and shoes from excavations and the collections regarding their meaning in the context of social action in concentration camps.

\section{Prisoner Societies in a Sociological Perspective}

The first sociological studies concerning National Socialist terror were conducted in the 1980s (Suderland 2014, see also Berger 1981). While Zygmut Bauman (1989) focuses on the norms and institutions that enabled the Holocaust, Wolfgang Sofsky's (1993) prominent study on the "Order of Terror" is a first example of a sociological attempt to explore the organization of violence in concentration camps. With particular regard to prisoner societies, it is the more recent work of Maja Suderland (2004, 2008, 2013, 2014) that deals intensively with social structures and processes in National Socialist concentration camps. Suderland (2013:8-9) builds her analysis predominantly on testimonies of survivors that reflect the contemporary witnesses' perception of possibilities and conditions for social interaction and practices during imprisonment. She demonstrates that even in an extreme environment such as the concentration camp there existed a differentiated stratification within the prisoner society. The preservation of the habitus, and thus also the continuation of social practices and modes of action enabled 
those prisoners who were able to act to remain social actors inside the camp (Suderland 2013:53-55).

The procedures and tortures to which prisoners were subjected when admitted to a concentration camp testify to the SS's desire to remove the prisoners' identity both in regard to their origin and social status acquired in the outside world as well as their usual ways of conduct, through humiliation and direct as well as subtle (symbolic) violence. The forceful removal of the few possessions inmates had brought with them, their clothes, the shaving of hair, the nakedness, the enforcement of wearing the blueand-white striped jacket and trousers of a wool-cotton fabric and wooden shoes (see also Iwaszko 2000; Schmid 2000), which Kogon (1946:44) calls "Dutch wooden shoes" are some characteristics of this degradation. The loss of an individual's own clothing and the loss of an individual's own name, replaced by the striped suit and a number, undoubtedly aimed to break the prisoners' will and humiliate them. It constitutes a complete exposure of the individual in the double sense: total surrender and dehumanization (Suderland 2013:116-123). The SS aimed to deliberately exclude prisoners from society (Neurath 2004:199). Former norms and laws, social positions, and stratifications were to be extinguished, any sociality and socialization destroyed. The inhuman treatment aimed to deprive the inmates of their own personality, individuality, identity, and any of the usual possibilities to act. Seemingly, any rules of social coexistence and communal life were abrogated in the confined cosmos of the camp.

Nevertheless Kogon and Neurath eloquently describe that after the shock caused by these tortures, newly admitted prisoners were quickly absorbed into certain groups that aimed to integrate the new arrivals. This seems to be particularly true for prisoners who shared certain ideological, political, or religious convictions with already established groups inside the camp (Neurath 2004:34-35), (e.g., political prisoners, but also Jehovah's Witnesses) (Neurath 2004:34-35). Jewish prisoners were admitted to specific barracks according to their racial backgrounds, which was determined by the Nazis, instead of their religious affiliation. Yet a sense of community persisted among them.

In particular, survivors who gave testimony early after their camp experience made it clear that there was a distinct hierarchy within the prisoners' society, fuelled by competition for leadership positions (Kogon 1946:255-259, Neurath 2004:340-356, see also Suderland 2013:160-162). This applies in the first place to so-called political and criminal prisoners who competed for influential positions within the camp. Ultimately, it was mostly political prisoners who managed to occupy key positions in the camps' organization (Häftlingsselbstverwaltung), a fact that Kogon as well as Neurath attribute to a better internal organization within this group of prisoners and thus also a stronger social structuring. This is confirmed by numerous other reports that were compiled in the course of the camps' liberation, where upon arrival the Allies were primarily supported by the political prisoners in order to gain control over the camps, install a first-aid infrastructure, and secure and record information on the SS's crimes.

Furthermore, the hierarchy within the prisoner society was also produced by the SS itself. Since it was impossible for the SS to control all processes inside the camp in their every detail, a system of so-called prisoner functionaries (Funktionshäftlinge) was established. This second camp hierarchy extended from the camp senior (Lagerältester) at the top, to the barrack leaders (Blockälteste), room leaders (Stubenälteste), and Kapos (from Italian capo $=$ leader). The tasks fulfilled by the prisoner functionaries 
were varied and included responsibilities for keeping order in the barracks, participating in the administration's record keeping, organizing the sick-bays and kitchens, or supervising work processes. This system offered the prisoner functionaries a certain, though always fragile access to power (Suderland 2013:192-205). Such prisoner functionaries could be recognized by some additional markers on the prisoner's clothing (e.g., the kapos wore a wide brassard with the inscription "KAPO").

In her work on the sociology of prisoner societies, Suderland (2013:244-245) demonstrates clearly that "basic concepts" (Neurath 2004:381) of what makes a human society, such as the human dignity of the individual and his/her social position and interaction with others, remained active even within the camp. In particular the habitus, which is integral to any person, shaped in early life and accompanies the sociality of all people in any situation without changing much, was not extinguished even in the extreme environment of a concentration camp, but only vanished with death, thus contributing to a differentiated prisoner society. Suderland (2013:52-111) bases her elaborations on Pierre Bourdieu's $(1985,1999,2001,2004)$ influential writings on the habitus, social space, and classes and employs his theories on the fundamental workings of human societies for her investigations into prisoner societies. In detail she demonstrates that the National Socialists' primary goal, to dehumanize people they did not consider parts of the Volksgemeinschaft, was achieved to a certain extent (see Suderland 2013:79-92). The extreme conditions forced the prisoners to adapt very quickly to the restrictive camp life in order to have any chance of survival. However, accounts of contemporary witnesses show that within only a few weeks of imprisonment "basic concepts" such as social differentiation, habitus, a sense of belonging, the relation of the individual and the group, social practices, former identities and individualities as well as modes of action - adapted to the conditions of the concentration camp - emerged again. Suderland even argues that due to the permanent threat and the National Socialists' attempt to extinguish social constants, prisoners reacted reflexively in a defensive way and tried to preserve social continuities by holding on to any possible kind of individuality. In this way, the prisoners preserved themselves as social actors who, although massively restricted, maintained a certain amount of agency. Here the economic, cultural and social capital available to the prisoners was of fundamental importance.

Suderland (2013:128-154) distinguishes three levels of sociality: first the military organization, which was regulated publicly and by the restrictive rules within the camp walls and strictly controlled daily routines. These included uniforms, both of the SS guards and the "zebra suit" of the prisoners (Suderland 2013:131). The second level Suderland refers to as the "shadow zone," where camp regulations were bypassed, although such behavior was partially tolerated by the SS. This level primarily comprises the unauthorized black market in the camps and illicit trading activities, which in many cases were fundamental to ensure a basic supply of necessary essentials for survival. In addition, Suderland includes in this level cultural activities that took place in secrecy but were partly ordered by the SS such as sporting competitions or music concerts. The third level is characterized by minutely organized, latent social life with its own, yet massively restricted scope of action. These levels, especially the second and third ones, allowed the prisoners to draw upon familiar ways of life and learned routines, perceptions, evaluation schemata, and their habitus in order to maintain a certain amount of agency. However, the extreme conditions in the concentration camps required modifications of familiar modes of behavior and action. 
For the concentration camps, Suderland (2004) points to cultural capital as key for survival. Cultural capital is not necessarily expressed only through material objects but also through education and literature, for example. It is manifested in practices such as reading newspapers or books in the little spare time available, eating in a "wellmannered" way, praying, and the (secret) reciting of poems during roll-call (Suderland 2004). However, for the material focus of this paper, artifacts from former camps created by prisoners from mainly scrap materials, such as spoons to enable the prisoner to eat, or combs to maintain a minimum of hygiene, but also decorating or crafting objects such as the prisoners' number tags (see Hausmair's article in this volume) have to be highlighted in this context.

Such practices belong to the second or third level. Some of them were certainly tolerated by the camp administration; others had to be conducted in secret and can only be described as individual, small-scale, and latent actions, which nevertheless shaped social life. These practices also served for self-assertion and can thus be interpreted as survival strategies (Theune 2013:250, 2016:65).

The social differentiation that becomes apparent in testimonies, historical records, and material culture therefore negates an approach that conceives of the prisoner society as a homogeneous community, a mass of prisoners. The complex structures within the prisoner society also produced a social space that could be viewed as a kind of distortion of the social space outside the camp walls (Suderland 2013:163).

\section{Clothing}

\section{Introduction}

Clothing is subject to different norms, habits, and traditions in different geographical areas of the world. Different styles and materials can protect us from the cold and heat or from exposure to the sun, wind, rain, and dirt, from environmental influences, from diseases, from hazards and injuries. In contrast to the rapid changes in the fashion of everyday clothing, the design and color of uniforms are usually more durable since they are supposed to be a continuously recognizable characteristic of formally defined groups such as the military. Both uniforms of the SS guards in concentration camps as well as the blue-and-white striped prisoner clothing that had to be worn by the inmates has to be understood in this context.

As a part of clothing, shoes have a special function since they protect our sensitive feet from injuries caused by contact with the ground. Constant standing, walking or carrying high loads in addition to our own body weight puts a lot of pressure on to our feet, thus demanding a capability for enormous performance and endurance. Wearing comfortable shoes is therefore of great importance to avoid fatigue to our feet, and thus a general bodily fatigue. Shoes help our feet to cope with the different kinds of stresses to which they are exposed (Andritzky et al. 1991; DeMello 2009).

Clothing and footwear not only fulfill functional purposes; they equally serve as a means of communication and can convey various messages (Justo 2005). If clothing has been chosen and put on voluntarily and consciously, it is a part of a person's selfexpression or may act as an identifier that signifies a sense of belonging to a group. Social status as well as individual personality can be expressed by clothing. Clothing can 
thus reflect a social and cultural identity and communicate it to others. Certain codes, which can be conveyed by clothes, constitute an integral part of the production of norms and group identities. If familiar with a group's social structure and communication system, others can recognize a person's status or class through his/her clothes. The use of clothing is therefore an integral part of Bourdieu's $(1999,2001)$ habitus theory.

\section{Prisoners' Clothes in Concentration Camps}

In concentration camps, clothes and uniforms were an essential aspect of the clearly recognizable distinction between prisoners and guards. Both the prisoners' clothing, which can also be regarded as a uniform, as well as the SS uniforms coded a group affiliation that was evident and ever-present for all in the camp. Until 1943, people admitted to a concentration camp were completely stripped of any personal clothes (see below). To replace their own clothing they received underwear, a shirt, the characteristic blue-and-white striped jacket and trousers, a cap, shoes (usually made from wood), and sometimes a pair of socks. The striped clothes were extremely recognizable, even from a great distance, and transformed the inmates into a large mass of more or less similar-looking, indistinguishable prisoners.

Triangular shaped textile badges of different colors were sewn on to the blue-andwhite striped jackets at chest height as well as on to the trousers and clearly indicated the position of the respective detainee as well as the reason for his/her imprisonment. Although badges were repeatedly incorrectly issued or distributed rather arbitrarily, they nevertheless visibly categorized the prisoners. Red triangles marked political prisoners, green triangles stood for "Professional Criminals," and purple ones for "Biblical Students" (Jehovah's Witnesses). Homosexuals were issued a pink badge, whereas prisoners deemed "asocial" and "work shy" (meaning unwilling to work) had to wear a black one. People of Roma or Sinti descent were marked as "Gypsies" with a brown triangle. The yellow triangle was issued to Jewish prisoners. In addition, letters written on to the badges indicated a prisoner's country of origin. In particular the Jewish prisoners often had to wear a second triangle that, in addition to their racial affiliation determined by the National Socialists, showed a further classification. A visual distinction on the basis of characteristic clothing, including the wooden shoes, was therefore permanent given that it distinguished prisoners and guards. What is crucial to note is that with the categorization through differently colored textile badges the uniformity of the prisoner societies was deconstructed by the SS itself.

The SS wore paramilitary uniforms consisting of a shirt, a tunic with a belt and shoulder strap, breeches, black jack-boots, and a visor cap, a wool cap, or a steel helmet. The obligatory skull insignia of the SS Death's Head Units was fitted to the collar. Undoubtedly, this uniform also contributed to the construction of masculinity and the ever-present power potential within the SS (see also Hackspiel-Mikosch 2009). The SS ranks could be read from the respective insignia on the shoulder boards, the collar, and the armband. As with most types of military clothes, the SS uniform, including the iron-shod boots, embodied military organization and clearly designated their wearers as members of the SS units. One may add that the iron heel plates mounted on the shoe soles, which is a common archaeological find during excavations in former concentration camps, certainly produced an audible sound when the SS guards walked through the camp. 
Mistreatment of the prisoners by kicks with the boots are repeatedly mentioned in survivors' memories and belonged to the usual torments inflicted by the guards.

The activity report of the administrative manager of Mauthausen provides an interesting insight into the camp's supply system and thus provisions for the inmates, which included clothing (Perz 2013). Deliveries of clothes for the prisoners or sewing machines for repairs are regularly noted in the report. Shoe deliveries are rarely mentioned, and wooden shoes not even once, which is striking when considering the important role the shoes occupy in survivors' memories (see also Pantouvaki 2014) as well as the large body of contemporary photographs that show inmates in wooden shoes. From the autumn of 1942, at the latest from February 1943, there were increasing problems with the upkeep of a sufficient supply of striped prisoner clothes due to a rapidly increasing number of inmates. To overcome the shortage of prisoner clothes, inmates were eventually left with either the clothes they wore when arriving or they were issued with clothes and shoes robbed from the countless victims who had been murdered in the large extermination camps in occupied Poland. These clothes were collected and then distributed among the concentration camps located further to the west, including Mauthausen, under the designation "Altbekleidung-Ost" (“Old Clothing East”) (Perz 2013:136, 193-194, see also Sudrow 2010:606-607). The colored triangular badges had to be attached to these civilian clothes in order to ensure the continuation of a clearly visible identification of prisoner. In the activity report it is also mentioned that old shoes of the SS that were no longer usable were given to the prisoners. However, the SS was supposed to provide the striped prisoner clothes to all inmates who were forced to work outside the camp walls in order to decrease the risk of escape.

Thus, in spite of the bad economic situation and general catastrophic conditions, there was at least a small possibility of preserving one's own identity and expressing it through clothing. The rigid division produced through the uniforms of the SS and the striped prisoners' clothing was partially disintegrating during the later stages of the camps' existence. Nevertheless, a clear distinction between prisoners and guards remained.

\section{The Sachsenhausen Shoe Testing Track and Shoe Factory}

In Sachsenhausen concentration camp, two facilities also attest to the importance of clothing and footwear during a time of scarcity of products and raw materials: the shoe testing track, which can be still seen in the memorial, and the shoe factory (Sudrow 2010:522-591). Even before the beginning of the war, the regime had issued a regulation that prescribed the use of substitute materials for the production of nonmilitary shoes in order to save on leather. As mentioned above, the maintenance of clothes played an important role in the concentration camps, and orders of sewing machines for repairs, but also for special sewing machines for shoes, is repeatedly noted in administrative records (Perz 2013). Most of the mending was done in the camps' workshops, but there are also clothes that show patchwork that was most likely done manually by prisoners in their scarce free time (see below). Workshops for shoe repairs existed in many camps and shoe companies like Salamander exploited concentration camp inmates as slave laborers for their shoe-production and quality control tasks (Sudrow 2010:610-612). The shoe factory in Sachsenhausen camp, however, fulfilled a special purpose (Sudrow 2010:606-626). 
The shoe factory in Sachsenhausen was established in the autumn of 1940 as a department of the Waffen-SS clothing work (Kaienburg 2006:280-287; Sudrow 2010:627-631) and was of special importance, since the Concentration Camp Inspectorate (the central office of all camps) was based in Sachsenhausen from 1938 onward. In the camp's industrial yard four barracks and a massive stone building were used for disassembling shoes and separating the various materials for further processing. There was also a large workshop for the production of prisoners' shoes. The disassembling of shoes was also aimed at searching prisoners' footwear for hidden valuables such as jewelry. The detainees who had to carry out this work were subject to special security regulations and penalty sanctions, in order to ensure that discovered valuables were handed over to the SS. Cavities, especially in the heels of shoes, were repeatedly used as hiding places for jewelry and other valuable small things. The shoe factory also produced wooden shoes for prisoners, which consisted of a wooden sole to which a leather textile was nailed. The production had to be significantly increased during the war years; therefore the number of prisoners who were forced to work in the shoe factory was increased significantly.

On behalf of several large shoe companies, new shoe models for the testing track were also manufactured in the shoe factory, while the need for shoes of all kinds, including work shoes and boots for the Wehrmacht, was immense. To further progress towards the attempted self-sufficiency of the National Socialist Empire despite a growing lack of various raw materials, a lot of effort was thus put into the development of plastics and new processing techniques. To ensure the quality and durability of newly developed materials, they were subjected to a practical material test.

The Sachsenhausen shoe testing track was built around the same time as the shoe factory in 1940 (Gottfried 2012; Sudrow 2010:526-591). The camp's entire roll-call square was encircled with a 700-m-long track, which was paved with seven different materials (concrete, slag, sand, damp clay, grit, gravel, and paving stones). Prisoners were forced to test shoes for the Wehrmacht and shoes from various large shoe factories of the German Reich by running across the testing track. As compensation for this labor, the companies had to pay six reichsmark to the camp administration for a day of testing. Up to 170 prisoners were given shoes every day. Without regard for their shoe size, they had to walk along the testing track for $9 \mathrm{~h}$ or up to $40 \mathrm{~km}$ a day while carrying luggage. Shoe companies tested their entire production in Sachsenhausen, including shoes for women which had to be tested by male prisoners. Many prisoners died through the exhausting test runs. Shoes were also subjected to laboratory tests. In addition to portable objects preserved from various camps, both facilities - the shoe factory and the testing track - highlight the importance of clothing and shoes within the concentration camp system.

\section{Material (Archaeological) Remains of Clothing and Shoes}

Finds made from organic material are rare in an archaeological context. Only when particular conditions for preservation are present do objects made from materials such as wood, leather, or fabric survive in the ground. In most cases, archaeology has only a very limited insight into objects made from these essential material groups, which have a high significance and a wide use in the everyday life of historic and prehistoric societies. This also applies to the archaeology at historical sites, including former 
concentration camps, forced labor camps, and other internment camps. After several years of exhaustive archaeological research at sites of National Socialist terror it is apparent that wooden shoes issued to the prisoners up to the end of 1942 do not appear in the archaeological record and rarely do textiles or residues of clothing. Nevertheless, historical sources such as the activity report of the Mauthausen administrative manager confirm several orders and deliveries of clothing for both SS and prisoners (Perz 2013).

We also know from evidence that rooms were filled, even crowded, with the detainees' personal belongings, including clothes and other personal valuables. After the liberation of the camps, the clothes stored in the buildings were issued, among other things, to the survivors or taken by the local population who was also in dire need of supplies. Lootings also occurred. The lack of archaeological finds, however, may also be related to the general lack of clothing. Apart from the few pieces permitted by the SS, inmates rarely possessed any other clothes and had to continue wearing their prisoner clothes after their liberation. An exception is the numerous textile finds from the former Gunskirchen sub-camp, which is located $55 \mathrm{~km}$ southwest of the Mauthausen concentration camp. The Gunskirchen camp existed for only a few weeks. It was built in the winter of 1944/45 during the last weeks of the war and was supposed to serve as a transit camp for the "evacuation" of mostly Jewish Hungarian prisoners, who first had been exploited for construction work at the southeast wall before being brutally driven from the east to Mauthausen. From there they were marched via Gunskirchen to the Ebensee sub-camp in order to prevent their rescue by the approaching Allied forces. Many barrack foundations are still visible in the wooded terrain at Gunskirchen. In the damp forest floor there are still numerous remains preserved from the last days of war, including textiles and leather shoes. There are no complete suits, trousers, or jackets, just fragmentary parts. One part belongs to a dark jacket or a coat with the button border and four buttons. Due to the damp environment, the color of the clothing is today black, but it may have been colored. The clothes seem to be civilian clothing and not the blue-and-white striped suit. Due to cost-intensive conservation, only a few textiles and shoes were recovered in the framework of a survey (Theune 2011).

Objects made from leather, including shoes, were slightly better preserved than other organic materials when found in garbage pits or other subterranean contexts in the camps since leather is more durable than wood or textiles. Shoes, be it completely preserved specimens or only parts, such as the upper, the sole, or metal heel plates are frequently found.

In Gunskirchen, several shoe parts lay on the forest ground, mostly men's shoes. One of the shoes taken for conservation and study is a left shoe with laces and nine thread eyes. Two characters are embossed in the leather: MÖ; these may be initials of the prisoner or a hint of the trade mark. Shoes are not only preserved in Gunskirchen, but also in many other locations. In Mauthausen, various shoes were found in the former disinfection bunker in camp section II. Among these shoes there are sandals, boots, lace-up shoes, men's shoes, women's shoes, and children's shoes. All these shoes are threadbare, probably not worth patching. The shoes are only individual items, there being no pairs of shoes, which would suggest cohesion and thus a planned disposal after liberation.

A larger number of shoes and shoe parts was found near the former concentration camp at Sachsenhausen (Weishaupt 2016). In the framework of a small archaeological 
excavation close to the northern edge of the camp a trench of ca. $10 \mathrm{~m}^{3}$ was discovered, filled entirely with shoe parts. These parts consists of soles, the leather upper, the leather heel, and other smaller parts. The objects supposedly stem from the Sachsenhausen shoe factory where shoes taken from the Nazis' victims in the extermination centers in Poland were checked for hidden valuables, processed, and then prepared for reuse. This means that the discovered shoe parts belonged to prisoners and, even if only preserved in a fragmented state, can provide clues regarding prisoners in the camps or their identity.

Clothes and shoes of the prisoners have also been preserved in the collections of memorials, which often hold examples of prisoners' striped suits and other clothes and shoes. In the collection of the Mauthausen memorial, 30 shoes are stored, along with two (Dutch) wooden shoes and shoes with a wooden sole. Furthermore, there are seven blue-and-white striped jackets and trousers, seven dresses, and two caps. Additionally, there are several triangular badges with the prisoners' numbers. In general these articles of clothing are in a good condition, but they also were darned many times. Other memorials of former concentration camps have similar collections.

Most of these items were donated to the memorials by survivors. They belong to the most symbolically charged objects and occupy an extremely important place in exhibitions. What needs to be kept in mind is that just as archaeological finds are only fragmented pieces of former material cultures, objects donated to or collected by memorials from non-archaeological contexts also constitute a very small range of material culture once produced and circulated in the camps. Certainly, these objects are not a representative selection of the former stock of things that would characterize prisoner society. The large display cases in the Auschwitz Memorial that are filled with staggering amounts of shoes, clothes, toothbrushes, spectacles, combs, and human hair refer to the countless victims murdered in Auschwitz-Birkenau and are intended to symbolize them.

\section{Clothing and Possibilities for Action}

Some examples of prisoners' clothing (e.g., from the Mauthausen Memorial) are very well preserved and offer an insight into the possibilities for action of the prisoners. Detailed examination shows heavy wear marks on some trousers and jackets, several of them with patchwork patches. Holes or wear marks are visible on the collars or sleeves, some of them covered with patches. Small cracks and holes have mostly been stuffed. A pair of trousers shows alterations that aimed to give the legs a tighter fit. The regularity or irregularity of the stitches indicate whether the repairs were made with a sewing machine or whether they had been done by hand or by a person with little experience. It can be assumed that manual repairs with needle and thread were usually done by the wearers of the jackets and trousers themselves, especially if the stitches are irregular. The same applies to civilian clothes that can be clearly identified as prisoners' clothing through colored triangular badges and prisoner numbers. Badges are often fitted to the clothes with irregular and simple stitches, indicating a lack of experience of the person who had sewn the badges on to the clothes.

On the other hand there are examples of patchwork which was clearly done with a sewing machine (e.g., trousers carrying a rectangular patch on the seat ; Fig. 1). In another case, several rectangular patches with trimmed edges are carefully sewn on to the worn 


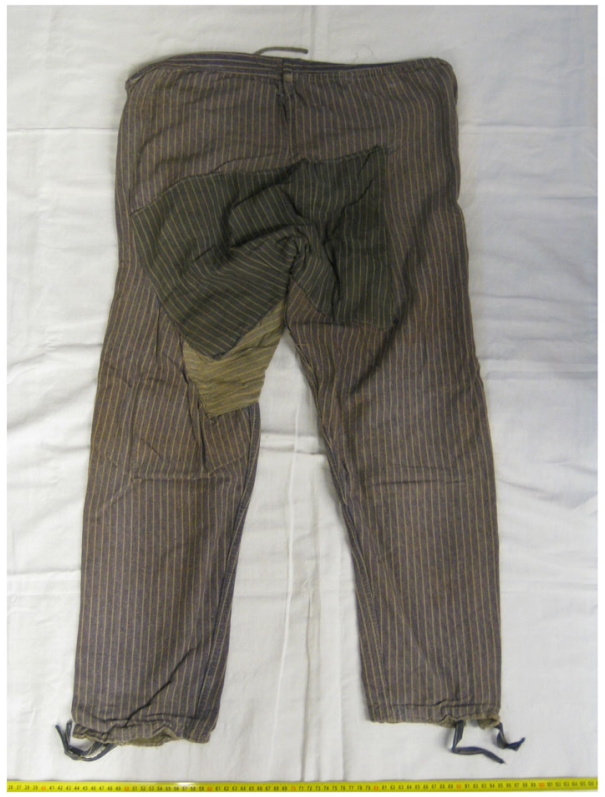

Fig. 1 Pair of trousers with several patches on the seat from Mauthausen. Copyright Marlene Schütze

fabric. Most of the preserved prisoner jackets do not have a full set of buttons but either lack some or have several different kinds of buttons, which also indicates repairs.

Another clear modification is a blue-and-white striped patch which is sewn on the back of a civilian dark fabric jacket. The prisoner did not have the whole striped suit itself, but the patch on the back made clear that he belonged to the group of prisoners.

In addition to the patches, some clothes are altered. A pocket made from a plain blue piece of fabric is sewn for example, onto the dress of a female prisoner. It is sewn on by hand with white thread (Fig. 2). The dress was thus modified in a way that would allow its wearer to carry small items with her.

Such alterations were visible to anyone in the public space of the concentration camp. Inmates saw the repairs, patches, and changes of their fellow-prisoners' clothes. The SS guards seem to have tolerated alterations such as additional pockets sewn on to dresses or changes to the width of trouser legs. These actions of the prisoners were related to the order and daily routines in the camp. The SS demanded of the prisoners to properly maintain their clothes. Therefore, such material traces of prisoner-made repairs and alterations can be assigned to the first (military organization) and second (shadow zone) level of practices after Suderland (2013:128-153).

But also the third level - minutely organized, latent social life - is represented in some of the preserved clothes. The Museum Kreis Genthin currently holds the prisoner suit of Wilhelm Seeger who was imprisoned in various concentration camps and in the jail in Brandenburg/Havel. A rectangular-shaped pocket made from striped fabric is sewn into the left inside of the jacket. A similar alteration is made to the above-mentioned civilian jacket with the blue-white striped patch on the back, stored in the Mauthausen collection. The black jacket has a velvet collar; at breast height is affixed the badge with the prisoner's number 65347 and a red triangle, showing that the owner was categorized as political prisoner. In the right 


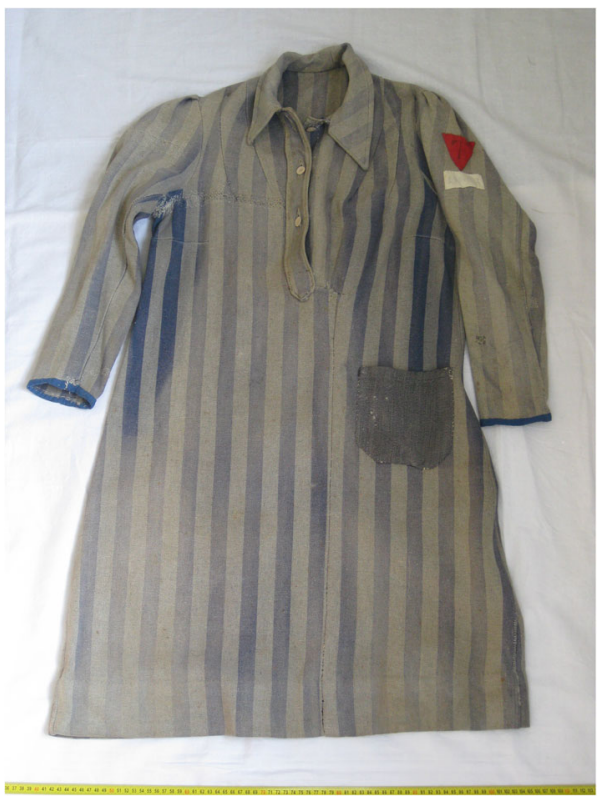

Fig. 2 Dress with pocket from Mauthausen. Copyright Marlene Schütze

inside of the jacket is a rectangular-shaped pocket sewn in by hand. On the pocket is a hand-made embroidery, where one of the owners or wearers marked the jacket with his initials $\mathrm{G}$ in yellow and $\mathrm{J}$ in red (Fig. 3). Prisoner number 65347 belongs to the Hungarian prisoner Rudolf Andorka, who was an envoy and who came to Mauthausen in May 1944. As the number and the initials don't fit together, it seems likely that a former owner or wearer with the initials G J marked the jacket, and Rudolf Andorka was a later person to wear the jacket in Mauthausen.

Neither pocket was visible from the outside. Not one stitch penetrates the entire fabric of either jacket, which suggests that they were intentionally fitted in a hidden

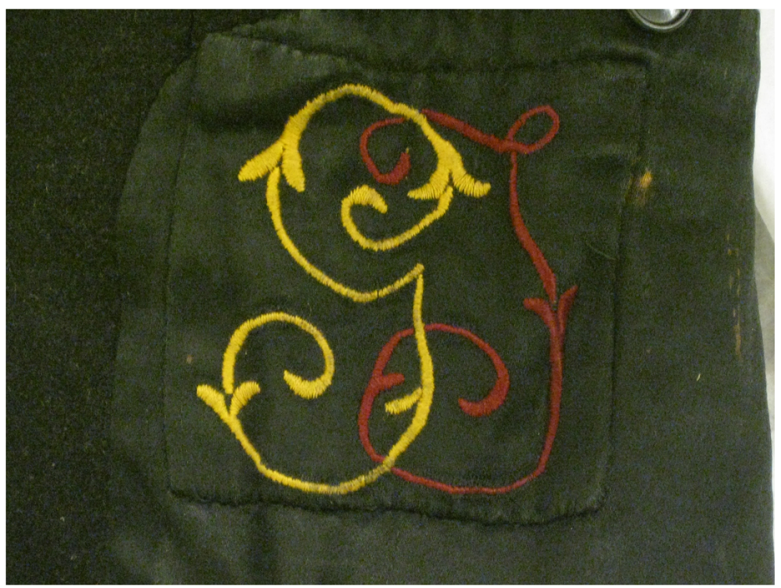

Fig. 3 Jacket with a pocket made and sewn in by a prisoner of the Mauthausen concentration camp. Copyright Marlene Schütze 
manner, probably aiming to conceal it from the view of others. It is no longer possible to determine if Wilhelm Seeger, G J, and Rudolf Andorka carried small flat items in these pockets that neither the guards nor other prisoners could see, or whether they kept personal valuables in them. In any case, it seems reasonable to suggest that they deliberately took a risk when fitting and/or using a secret pocket in their jackets for transporting or safe-keeping small items. The initials $\mathrm{G} J$ on the pocket from the Mauthausen camp can additionally be interpreted as sign of emphasizing his identity as a man with a name; at this same point on the outside of the jacket is placed the badge with the number that the Nazis gave Rudolf Andorka.

An even more extensive and secretly conducted manipulation of clothes is accounted for by contemporary witnesses. Some former inmates report that many prisoners tried repeatedly to hide valuable items or notes by sewing them into their clothes in order to conceal them from the ever-present gaze of the SS. Archaeologically, it is almost impossible to trace such practices due to the usually bad preservation of textiles. Nevertheless, such actions are sufficiently attested to by other sources.

\section{Shoes}

The Mauthausen Memorial holds several shoes in its collection. Most of the plastic and leather ones derive from archaeological contexts. It is not always the case that today's place of storage coincides with the place where an item was found or originated, since objects from former camps are passed between memorials and museums. However, they are always objects from former concentration camps. Due to the early collecting activities and a subsequent storage in archives with controlled, dry environments, some wooden shoes and/or wooden soles have also been preserved. Overall, wooden shoes or soles made walking or long periods of standing extremely uncomfortable since the inflexible material did not allow for a healthy movement of the foot.

The so-called "Dutch clogs," heavy shoes made from one piece of wood, have a slightly elevated heel and pointed tip (Fig. 4). If the wood is not smoothed in the shoe's insides or edges, there is a high risk of getting sore feet through friction when walking.

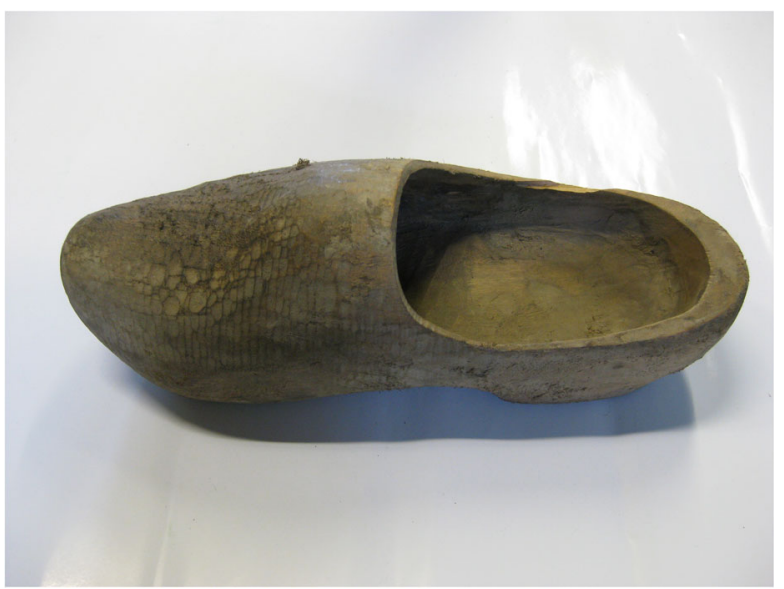

Fig. 4 Wooden shoe from Mauthausen. Copyright Marlene Schütze 
Many survivors recall painful sores on their feet from wearing clogs (see also Pantouvaki 2014:28).

Far more common than clogs appear to be shoes with only wooden soles. As noted above, such shoes were also produced in large numbers in the Sachsenhausen shoe factory. The sole is only slightly ergonomically shaped. The upper made from leather and fabric was basted with small nails and provided minimum support for the foot. Photographs taken in concentration camps clearly show that such shoes were not always of the prisoner's actual size and were usually worn without socks, making it difficult to stand firmly. The uncomfortable footwear added just another physical torment to the permanent agony prisoners had to endure through the SS. All preserved shoes show substantial marks of wear and tear; many are patched and repaired multiple times. Here again, a distinction can be made between a skilled or professional repairs and less expert ones.

Some shoes are made from leather and show a broad range of shapes and styles, such as boots and sandals. This is due to their original production for civilian usage. Only from 1942/43 onward were such shoes issued to prisoners in the camps due to the already mentioned shortage in supply of wooden shoes. Again, numerous patches and repairs illustrate the recurring necessity for the repair of the heavily worn shoes.

One prisoner-made shoe discovered in Mauthausen is particularly noteworthy (Theune 2015) (Fig. 5). The sole consists of several layers of rubber that have been trimmed following roughly the shape of a foot of US size 7 (UK size 5; EU 38). Six layers of rubber - most likely cut from an old car tire - are fitted on top of each other and held together with nails. The heel is additionally fitted with an extra piece of rubber. Although badly preserved, residues of some kind of fabric fixed to the sole suggest that the handmade item also had a closed upper probably for providing some protection for the foot. Another piece of rubber that is fixed between the different layers of the rubber sole served as a strap to keep the shoe attached to the foot. There are also residues of another strap in the toe area. The shoe suggests that the shoe supply for prisoners had become completely inadequate at some point and the prisoner who had crafted the shoe in question was probably forced to do so to have at least a minimum of protection for his or her feet.

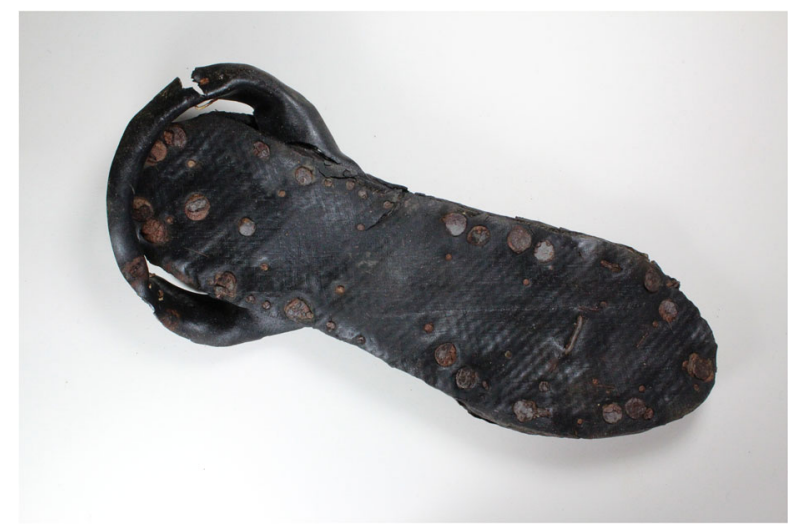

Fig. 5 A prisoner-made shoe from Mauthausen. Copyright: Claudia Theune 
Shoes are a part of clothing that is always visible. Prisoners and guards were able to see each other's shoes in camp. Whether an inmate had good (pre-camp) shoes or had to wear the bulky wooden shoes handed out by the camp administration or was even forced to produce a substitute due to a lack of any provision - all of this was visible. The patches or self-manufactured shoes have to be assigned to Suderland's first and second level. Although camp regulations may have been breached, it seems likely that such alterations or self-made items were tolerated. The quality of the shoes may also be indicative of a prisoner's status within camp hierarchy. Good leather shoes with a flexible, sturdy sole, a high shaft for a secure hold are most likely to be attributed to prisoners who had access to good products. In contrast, shoes made from car tires and other waste materials show that some prisoners were able to get hold of resources to produce their own clothing, although the quality of accessible materials and possibilities to process them were very limited, suggesting that such prisoners had a relatively low status within the camp.

The hiding of small valuables in clothes or the heels of shoes attests to individual manipulation performed by prisoners. Such acts were possibly carried out before people were deported to the camps and manifest an attempt to save important personal belongings or souvenirs, but still confirm the third level of Suderland. Knowing that the SS would try to collect all personal possessions, some prisoners also tried to keep important (small) things secret and hide them from the SS. These actions correspond to the hiding and sewing of valuables into clothing before deportation. The SS noticed such attempts early on, which lead to routinely conducted searches through clothes and shoes (Sudrow 2010).

\section{Pseudo-Uniforms for Prisoner Functionaries}

How effectively power can be constructed through clothing is also demonstrated by Barbara Hausmair's (2016) analysis of pseudo-uniforms worn by prisoner functionaries in Mauthausen. During excavations of the SS areas in Mauthausen in 2002 four steel helmets of the M16 type were discovered. This model had been in use by the German army since the First World War and was then replaced by a lighter model - the M35 in 1935. Some of the helmets discovered in Mauthausen are fitted with an iron spike, so that at first glance they resemble the traditional "pimple" helmets of the Imperial German Army. Residues of white paint indicate that these helmets also had been coated with a bright color (Fig. 6). In a photograph from 1941 or 1942 two prisoner functionaries of the so-called camp police are wearing such white helmets with attached spikes. In addition, the two men are wearing uniforms consisting of a tunic, belt, sabers, trousers, and jack-boots that appear to be too large for them. It is very likely that these uniforms were also worn-out pieces from the pre-Nazi period. In the photo, the two camp policemen are inspecting Soviet prisoners-of-war who have just arrived at the camp. The uniforms give them a military appearance, in which the Imperial period is referenced through the pseudo-"pimple" helmets.

The uniforms, including the altered helmets and sabers, and thus the military appearance of the so-called camp police, were deliberately created by the SS. On the one hand, these clothes should produce a clear distinction between the ordinary prisoners and the special position of the camp police. On the other hand, the anachronistic and worn-out uniforms clearly contrast the modern and smart uniforms of the SS 


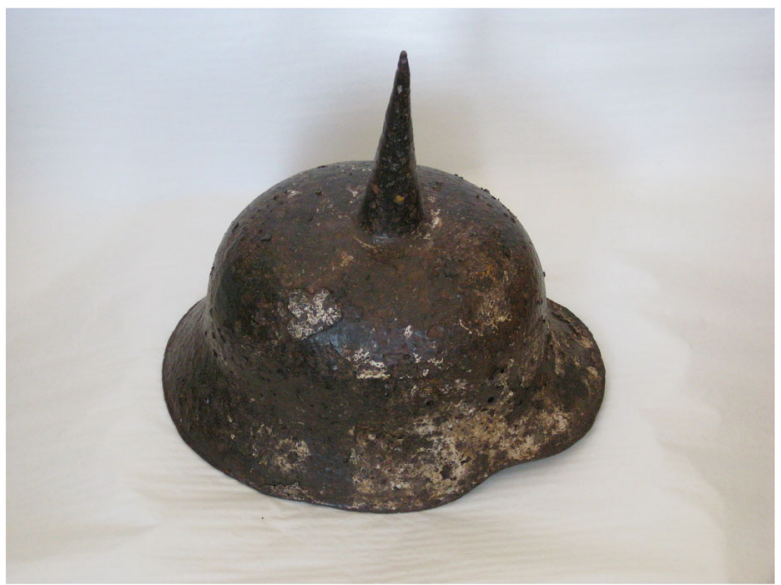

Fig. 6 White-coated helmet with a fitted iron spike. Copyright: Judith Benedix

units. The latter wear uniforms that are perfectly tailored to their size and shape and are in very good condition. Rank and the affiliation to the SS Death Head's units are clearly visible through the insignia on the collar. The clothes, therefore, are clearly hierarchized in the sense of Suderland's first level as well as military organization, which was regulated by the camp administration, materializing positions of power through clothing. Within the prisoner society the camp police occupied a privileged position, which in this case was not only displayed markings such as colored triangles or prisoner number, but also through pseudo-uniforms.

\section{Conclusions}

The discussed examples all present actions incorporating clothes: the wearing, mending, and altering of clothes or the enforcement to test new shoes for the Reich's industry which also has to be understood as a kind of punishment. All these actions were either ordered by the SS, tolerated by the perpetrators, or concealed from the eyes of the SS and conducted in secrecy. Therefore, these actions can be attributed to the three levels of sociality suggested by Suderland. In addition to the (first) military organization, a second level - the so-called "shadow level" - that consisted of tolerated actions can be observed, as can Suderland's third level, which describes possibilities for minutely organized latent social life. The testing of shoes on the Sachsenhausen shoe testing track presents an example of the cruel first, military level. The SS also demanded that the prisoners properly care for the clothes that had been issued to them. Patches and mending found on prisoners' clothes refer to actions of the inmates that aimed to satisfy the SS's orders and thus also belong to Suderland's first level. Maintenance and repairs of clothes were conducted in very different ways though and in some instance the observable alterations certainly do not qualify as repairs but constitute individual improvements of clothes. Some of such alterations were worn visibly and thus seem to have been tolerated by the SS. Other alterations, such as the hidden pocket sewn into Wilhelm Seeger's and G J's/Rudolf Andorka's prisoner jackets, point towards secretive actions that had to be concealed but were nevertheless possible. 
The different scopes for action or forced action as observable in clothing can provide insights into the differentiation of prisoner societies inside concentration camps. In addition to the SS's brutal employment of clothing as signifier for the differentiation of the guards and the guarded as well as a means for punitive action (shoe testing), the examples presented also provide indications for the use of clothing in the sense of survival strategies of the prisoners in former concentration camps.

Acknowledgments Open access funding provided by University of Vienna. I wish to thank first and foremost Barbara Hausmair and Judith Benedix for many useful discussions. Barbara Hausmair has kindly translated this chapter into English, and Gilly Carr has made a careful copy-edit.

This research was conducted in the framework of the research cluster "Diktaturen, Gewalt Genozide" (Dictatorships, Violence, Genocides) of the Faculty of Historical and Cultural Studies, University of Vienna.

Open Access This article is distributed under the terms of the Creative Commons Attribution 4.0 International License (http://creativecommons.org/licenses/by/4.0/), which permits unrestricted use, distribution, and reproduction in any medium, provided you give appropriate credit to the original author(s) and the source, provide a link to the Creative Commons license, and indicate if changes were made.

\section{References}

Andritzky, M., Kämpf, G., and Link, V. (1991). z.B. Schuhe. Vom bloßen Fuß zum Stöckelschuh. Eine Kulturgeschichte der Fußbekleidung, Anabas Verlag, Giessen.

Bauman, Z. (1989). Modernity and the Holocaust, Cornell University Press, Ithaca.

Berger, T. (1981). Lebenssituationen unter der Herrschaft des Nationalsozialismus, Hirschgraben-Verlag, Frankfurt am Main.

Bourdieu, P. (1985). Sozialer Raum und "Klassen.” In Bourdieu, P., ed., Sozialer Raum und "Klassen." Zwei Vorlesungen, Suhrkamp, Frankfurt am Main, pp. 7-46.

Bourdieu, P. (1999). Die feinen Unterschiede. In Kritik der gesellschaftlichen Urteilskraft, Frankfurt am Main, Suhrkamp.

Bourdieu, P. (2001). Habitus und Einverleibung. In Bourdieu, P. (ed.), Meditationen. Zur Kritik der scholastischen Vernunft, Suhrkamp, Frankfurt am Main, pp. 177-182.

Bourdieu, P. (2004). Schwierige Interdisziplinarität. Zum Verhältnis von Soziologie und Geschichtswissenschaft, Westfälisches Dampfboot, Münster.

DeMello, M. (2009). Feet and Footwear, Greenwood Press, Santa Barbara.

Gottfried, C. (2012). Konsum und Verbrechen - die Schuhlaufstrecke im KZ-Sachsenhausen. In LVRIndustriemuseum Ratingen (ed.), Glanz und Grauen. Mode im "Dritten Reich". Begleitbroschüre zur Sonderausstellung, Druckverlag Kettler GmbH, Bönen/Westfalen, pp. 50-53.

Hackspiel-Mikosch, E. (2009). Uniforms and the creation of ideal masculinity. In McNeil, P., ed., The Men's Fashion Reader, Berg, New York, pp. 117-129.

Hausmair, B. (2016). Jenseits des "Sichtbarmachens" - Überlegungen zur Relevanz materieller Kultur für die Erforschung nationalsozialistischer Lager am Beispiel Mauthausen. In Kersting, T., Theune, C., Drieschner, A., Ley, A., and Lutz, T. (eds.), Archäologie und Gedächtnis. NS-Lagerstandorte Erforschen - Bewahren - Vermitteln, Michael lmhof Verlag, Petersberg, pp. 31-46.

Iwaszko, T. (2000). The housing, clothing and feeding of the prisoners. In Długoborski, W., and Piper, P. (eds.), Auschwitz 1940-1945. Central Issues in the History of the Camp, Vol. I-V, Auschwitz-Birkenau State Museum, Oświęcim.

Justo, G. (2005). Kleidung als Mittel nonverbaler Kommunikation und Selbstdarstellung, Diplomica Verlag, Hamburg.

Kaienburg, H. (2006). Der Militär- und Wirtschaftskomplex der SS im KZ-Standort SachsenhausenOranienburg. Schnittpunkt von KZ-System, Waffen-SS und Judenmord (Schriftenreihe der Stiftung Brandenburgische Gedenkstätten), Metropol-Verlag, Berlin.

Kogon, E. (1946). Der SS-Staat. Das System der Deutschen Konzentrationslager, Verlag der Frankfurter Hefte, Frankfurt am Main. 
Neurath, P. M. (2004). Die Gesellschaft des Terrors. Innenansichten der Konzentrationslager Dachau und Buchenwald. Suhrkamp Verlag, Frankfurt am Main. 2005: The Society of Terror. Inside the Dachau and Buchenwald Concentration Camps. Paradigm Publishers, Boulder.

Pantouvaki, S. (2014). Narratives of clothing. Concentration camp dress as companion to survival. International Journal of Fashion Studies 1(1): 19-37.

Perz, B. (2013). Verwaltete Gewalt. Der Tätigkeitsbericht des Verwaltungsführers im Konzentrationslager Mauthausen 1941-1944, Mauthausen-Studien. Schriftenreihe der KZ-gedenkstätte Mauthausen Band 8. Bundesministerium des Inneren, Wien.

Schmid, B. (2000). Geschichte und Symbolik der gestreiften KZ-Häftlingsbekleidung. Doctoral dissertation, University of Oldenburg.

Sofsky, W. (1993). Die Ordnung des Terrors. Fischer, Frankfurt am Main. 2013: The order of terror: the concentration camp. Princeton University Press, Princeton.

Sturdy Colls, C. (2015). Holocaust Archaeologies. Approaches and Future Directions, Springer, New York.

Suderland, M. (2004). Territorien des Selbst, kulturelle Identität als Ressource für das tägliche Überleben im Konzentrationslager, Campus-Verlag, Frankfurt am Main.

Suderland, M. (2008). Die schlafende Kraft des Habitus. Über verborgene Herrschaftsstrukturen in der Häftlingsgesellschaft nationalsozialistischer Konzentrationslager. In Schmidt, R., and Woltersdorff, V. (eds.), Symbolische Gewalt. Herrschaftsanalyse nach Pierre Bourdieu, UVK-Verlag, Konstanz, pp. 245-268.

Suderland, M. (2013). Inside Concentration Camps. Social Life at the Extremes, Aus dem Deutschen übersetzt von Jessica Spengler, Polity, Cambridge.

Suderland, M. (2014). Das Konzentrationslager als giftigste Beule des Terrors. Soziologische Perspektiven auf die nationalsozialistischen Zwangslager. In Christ, M., and Suderland, M. (eds.), Soziologie und Nationalsozialismus. Positionen, Debatten, Perspektiven, Suhrkamp-Verlag, Frankfurt am Main, pp. 365-405.

Sudrow, A. (2010). Der Schuh im Nationalsozialismus. Eine Produktgeschichte im deutsch-britischamerikanischen Vergleich, Wallstein, Göttingen.

Theune, C. (2011). Bericht über den archäologischen Survey auf dem Gelände des ehemaligen Konzentrationslagers /Außenlager Gunskirchen. Unpublished report, Vienna.

Theune, C. (2013). Archaeology and remembrance: the contemporary archaeology of concentration camps, prisoner-of-war camps and battlefields. In Mehler, N., ed., Historical Archaeology in Central Europe, Society of Historical Archaeology, Rockville, pp. 241-260.

Theune, C. (2015). Ein Schuh aus dem Konzentrationslager Mauthausen. Sonius. Archäologische Botschaften aus Oberösterreich 17: 9-10.

Theune, C. (2016). Archäologie an Tatorten des 20. Jahrhunderts. 2. durchgesehene und erweiterte Auflage, Wissenschaftliche Buchgesellschaft, Darmstadt.

Weishaupt, J. (2016). Archäologie in Gedenkstätten - Anlässe und Ergebnisse. In Kersting, T., Theune, C.L., Drieschner, A., Ley, A., Lutz, T. eds., Archäologie und Gedächtnis. NS-Lagerstandorte Erforschen Bewahren - Vermitteln. Interdisziplinäre Konferenz im Archäologischen Landesmuseum Brandenburg an der Havel 17. bis 19. September 2015. Michael Imhof Verlag, Petersberg, pp. 63-69. 